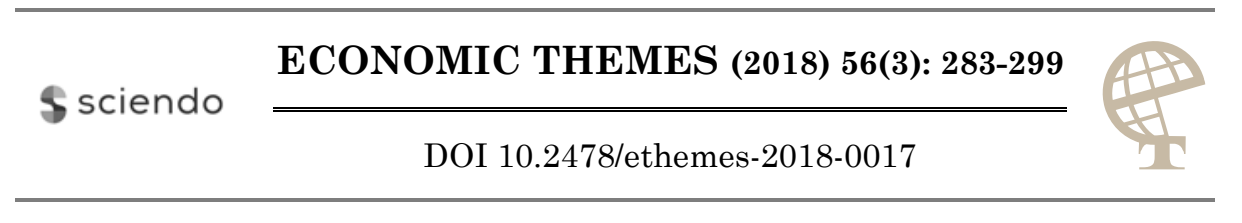

\title{
EFFECTS OF THE APPLICATION OF THE CRM CONCEPT TO PROFITABILITY OF THE BANKS*
}

\author{
Suzana Stevanović \\ Faculty of Business Economics Bijeljina, University of Istočno Sarajevo, \\ Bosnia and Herzegovina \\ $\bowtie$ suzana.stevanovic@fpe.unssa.rs.ba \\ Zvjezdana Gavrilović \\ Faculty of Business Economics Bijeljina, University of Istočno Sarajevo, \\ Bosnia and Herzegovina \\ $\bowtie$ zvjezdana.gavrilovic@fpe.unssa.rs.ba
}

UDC
$658.89: 336$.
711

Review

paper

Received:

01.12.2017

Accepted:

28.05.2018

\begin{abstract}
CRM (Consumer Relationship Management) is a recent concept. Development and introduction of this concept in the banking operations started in the ' $90 \mathrm{~s}$. Due to complex market conditions and the current environment in which banks operate, it is necessary to have a new method for doing business, which will provide quick and efficient recognition of clients. This business concept entirely replaces the traditional operating methods of the bank, where the focus is on clients, their needs, and wishes. The CRM concept enables the bank to respond to the individualized demands of the clients with quality banking products and services. With this, the banks manage to deal with the tough competition and make a profit. The goal of this paper is to examine the importance, development, and implementation of the CRM in the banks. The paper tries to prove the hypothesis: Introduction of the CRM philosophy in the banking operations leads to increased profitability of the bank.
\end{abstract}

Keywords: CRM concept, profitability, banking sector

JEL classification: D12, G21

\footnotetext{
* The paper has been presented at the International Scientific Conference: "Contemporary approaches in the analysis of economic performances", held at the Faculty of Economics, University of Niš (Prolom Banja), October 11-12, 2017.
} 


\section{Introduction}

$C R M$ as a concept represents the harmonisation of business strategies and goals by means of reviewing the needs and requests of the customers. The customers are in the focus, representing the centre of all business events and activities. Without application of the appropriate information-communication technologies, it is not possible to implement the quality analysis of the market and the customers, which means that there were significant changes in the approach to the marketing, preparation of the strategies and development of institutions. So, the institutions, by means of the developed information-communication networks, at any given moment have the information available on each of their customers, and the database is being continuously updated. With emerging of the CRM concept, a development of the various programme packages occurred, which support the application of the CRM strategy, and which is automated for many of the characteristics. Customer Relationship Management-CRM represents the alignment of business strategy and the organisational structure and company cultures, getting the information about the costumers in order to achieve business benefits and profits.

The paper is segmented into four parts. The first part includes defining of the term of CRM components, as well as its components. The second part of the paper shows and explains the role and importance of CRM and the necessity of introducing this strategy in the company. The third part includes research in relation to the development and application of CRM in the banking sector. The fourth part shows the effects of the implementation of e CRM to the profitability of the banks. The conclusions and research results are included in the fifth part of the paper.

\section{The term and components of the $C R M$ concept}

The CRM (Consumer relationship management) concept is defined differently by different authors. This concept is getting increasingly important in all areas of business, including the banking. CRM represents a new management concept, i.e. new approach to management of long-term relationships with the consumers (Unković M., Stakić B. 275-276; 2011). Kotler and Keller (2006) define the management of consumer relationships as the process of management of the detailed information on consumers and careful management of all points of contact with the consumers in the purpose of maximising their loyalty.

Parvitayar and Sheth (2001) defined CRM as a comprehensive strategy, a process that focuses on attracting, retaining and building partnerships with selected segments of consumers in order to create superior value, both for them and for the company itself. Based on a specific database and appropriate CRM software, it integrates and optimises processes related to client relationships in various areas: marketing, distribution, customer service, and research and development.

According to Frrencouise Tourniaire (2003), CRM presents: 
1. The whole field of customer relationship management, which consists of customer-oriented functions such as marketing, sales and customer support;

2. Tools used by functions such as sales force automation;

3. Something between the previous two, the process involved in customer relationship management.

Modern banking operations start with the CRM strategy. According to this opinion, the centre of interest for the bank is the client. In order for the bank to develop and its position on the market, it is necessary to keep information about its clients.

The development of this concept is associated with the 1990s of the last century, following the expansion of IT technologies. In beginning, this concept was observed as a part of the software, but it has evolved into a separate business philosophy, which represents the new methods for doing business.

The introduction of CRM into the organisation does not represent only a training of employees for use of the new technologies for approaching the customers, but also a total shift in the approach, and also in the reasoning of the employees, from highest to the lowest level of hierarchy in a company. This also represents a problem, because it is proved through the business practice, that the biggest fear of the employee is change. On the other side, for the company, the application of the CRM concept represents a key to success.

The CRM concept in this sense represents a tool which helps to build and maintain the long-term relationships with customers. With the appearance of new complex conditions in the market, the CRM represents a good response to such specific market requirements. The CRM enables overcoming of the crisis situations which occur frequently in the market.

The base and support for conceiving and implementation of the CRM strategy for the bank is provided by the so-called IDIC model, which includes the four elements or steps: (Peppers D, Rogers M, 2004, 68-69)

1. Identify customers;

2. Differentiate customers;

3. Interact with customers;

4. Customise treatment.

These stages in the implementation process for CRM strategy rest on specificities of the marketing strategy and establishing of the appropriate relationships with the customers, which imply the specificity, diversity, individual needs and requests of the customers.

If we approach the CRM architecture as a whole, then the following main areas are observed: environment, organisation, infrastructure, structure, adjustment, and integration. (www.ef.uns.ac.rs) 
Figure 1. CRM Architecture - processes, contact points and unique views of users
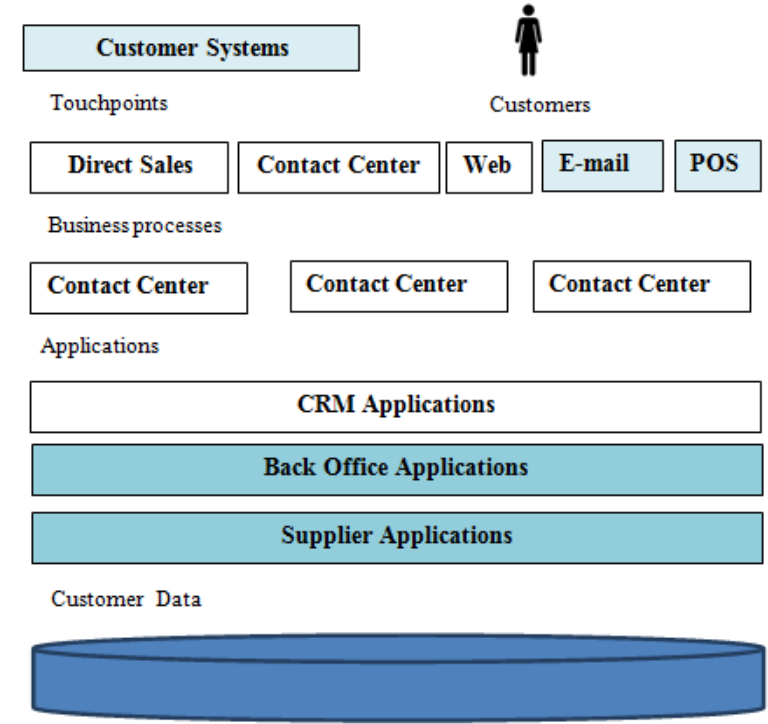

Source:

http://www.ef.uns.ac.rs/Download/elektronsko_upravljanje_odnosima_sa_kupcima/2014-0326-CRM-Definicija.pdf

Various classifications of CRM are present, so there are:

1. Operational $C R M$

2. Collaborative $C R M$

3. Analytical CRM and

4. Strategic $C R M$.

Operational CRM refers to the entry of data on interactions with customers, through various databases and applications for monitoring of their activities. So, in this segment of $C R M$, information is stored in the database without prior analysis. In order to make certain conclusions from the collected data, it is necessary that this is done by the operators who are specifically trained for that and who have certain experience.

Concerning Analytical CRM, it can be said that this segment is the most complex and of course most expensive part of the entire CRM system. In this segment, a detailed analysis of the collected data is done, which are based on the expert knowledge. On basis of the analyses, it is possible to create an individual image of each customer, his/her individual profile, needs and wants, all in the goal of strengthening of the mutual interactions. The data are collected from various sources: list of articles, analysis of deliveries, and history of work orders), as well as the 
marketing analysis. All of the data can be processed with the data mining method or OLAP analysis.

Analytical CRM consists of: pattern discovery; products, customers, and services analysis; sorting and customer fractionation and customer value evaluation. (www.tutorialreports.com)

Collaborative or organisational CRM implies establishing the interaction with the customers both by means of traditional (phone, fax, mail) and modern media (SMS, Web, e-mail). With the interactive use of media the system sends customers the notifications, offers etc., and responses of the users are returning to the system through operational CRM. (Zelenović V, 2012, 126)

The application of any of these three elements represents a CRM strategy, i.e. customer relationship management. Successfulness of the implementation of CRM concept imposes the requirements that all of its mentioned elements are harmonised as a whole.

\section{The importance and role of CRM}

The role of CRM is reflected in the effective implementation of the company's business strategy and objectives through the prism of the needs and demands of clients. This concept focuses on the harmonisation of business strategies, the structure of the organisation based on the collection, processing and use of information, all in order to satisfy clients, by meeting all their needs, in order to achieve the ultimate result, benefits and profit for the company. With this strategy, clients are placed in the focus of all business events, with defining key clients.

The modern market environment imposes the need to change the methods in the application of marketing, where the primacy is given to innovative solutions in the field of information and communication technologies. The development of these innovative technologies, especially the Internet, through the computer network, enables direct connection between supply and demand in the market. CRM represents a segment of an electronic business, which was primarily conceived as a philosophy. The emergence of this philosophy has led to the development of many software packages that implement CRM strategies, where the system is more automated. In terms of providing information, it is also the basis for business decision-making in the definition of market positions. So, the usage of this technology shall be a fundamental change in the philosophy of customer relationships in the organisation.

It has been proven through business practices that are the largest employee fear change. On the other hand, for the company, this is the key to success through the implementation of this concept. 
Financial institutions place their products and services on the market and their value is created on the financial markets. In recent years, there have been significant changes in the functioning of financial institutions, which are reflected in the changes related to the provision of financial services. The development of the interactive relationship between the client and the financial institution is based on the exchange of information, where both sides are constantly exposed to learning from experience. From these relationships financial institutions to collect information, which is later used for the analysis of future performances to customers, in order to create its longterm loyalty.

The effectiveness of CRM processes, through the integration of marketing activities, includes the following:

1. Identification of factors that contribute to a successful relationship with consumers.

2. Development practices in their relations with consumers.

3. Development process which will benefit consumers.

4. Formulating questions that would help in addressing potential consumers' problems in the most adequate way.

5. Recommendations for consumers who have complaints about the product/service.

6. Sales tracking and consumer support.

The reasons why the implementation of CRM has created a competitive advantage for bank are the following (http://www.preact.co.uk/why_crm/howbusinesses-benefit):

- Data processing in real time to make better, more accurate management decisions.

- Better organisation of staff time, because the CRM system focuses on activities to individual customers sorted by priority.

- Improving and better targeting marketing activities to improve client segmentation and targeting.

- More accurate analytical reports, which serve as a basis for forecasting sales as a cash flow bank.

- Reduced response times for customers' inquiries, as well as faster time of correction and exploitation of business opportunities.

- Continuous monitoring of sales results and customer satisfaction, which enables better control of customer relationships and possible mismatch.

- Automation of the business process due to better distribution of working time.

- It promotes teamwork and improves relationships within the bank, due to the introduction of all employees with the bank's objectives as well as the monitoring of progress on these goals.

- CRM connects accounting and back-office applications to join in sales processes. 
- Automatic verification of previous orders of individual clients as well as access to all other information.

- Integration of all business processes into one information system.

- Increased efficiency of sales activities due to better assessment of the effectiveness of the project.

- The protection of private customer data.

- The education of existing but also new employees is shortened by the standardisation of business processes as well as clear instructions for performance by sector of the company.

\section{Application of the $C R M$ concept on the banking sector}

Since the survival and further development of banks depend on providing of added values, their orientation is directed to deeper business cooperation with the customers. Introduction of the CRM in the banks imposes itself as a need, since the researches are showing that the bank customers are increasingly more dynamic, and increasingly less loyal. The relationship between the bank and the customers does not represent only a simple sum of implemented transactions in the past. (Parasuraman A, Zeithaml, V.A, \& Berry, L.L, 1988, 12-40)

Essentially, CRM is a business strategy of the bank, which requires a complete reorganisation of business processes in the bank. In order to be successful, the implementation of this strategy requires the application of appropriate software solutions and information technology tailored to the specifics of operations of individual banks. As the main motivation of each company is profit, which can be present in their business in the long run if models are found for the long-term successful satisfaction of the needs of the clients of the bank. Implementation of long-term relationships with clients is possible with good practice and experience with appropriate CRM software, which can lead to the realisation of the vision of the bank.

In order to successfully apply the CRM strategy in the banks, the trust factor is of crucial importance. In the sense, this represents the ability to create long-term loyal customers, where the sense of closeness and affiliation will develop. Most frequent "reason which lies at the base of the dissatisfaction and abandoning by the customers is that the customers were not satisfied with the value they have been receiving" (Arsovski S, 2002). This trust results from common goals, respecting of the same system of values, as well as ability to predict the reaction of the other side.

In order to implement the CRM concept in the banks, it is required to have high monetary investments in information technology, certain software, as well as to train the personnel. With the application of CRM, the banks are trying to realise some of the following goals: retaining customer loyalty, personal service to customers, better knowledge about the customer, increase in profitability of an individual customer, 
differentiation from the competition, identification of the profitable customers, attraction of new customers, decreasing of costs with improvement of customer services, decreasing the costs for attraction of new customers. (Sexauer H.J, Reimann E, 2006)

According to the research of the author R. Forsyth (Forsyth R, 2001), the most frequent reasons for poor implementation of the CRM system are the following: organisational changes (29\%), business policy of the company $(22 \%)$, poor understanding of the CRM $(20 \%)$, and incompetence of the implementers $(9 \%)$.

Implementation of CRM in the business system of the bank's long-term, which was never fully completed. The fact is that the demands of clients increased in parallel with the growth of innovative technology and customer awareness of the need to be seen as the most important link in the chain of production and continuously maintained at a high level.

Figure 2. Costs and benefits of CRM for the bank and its clients

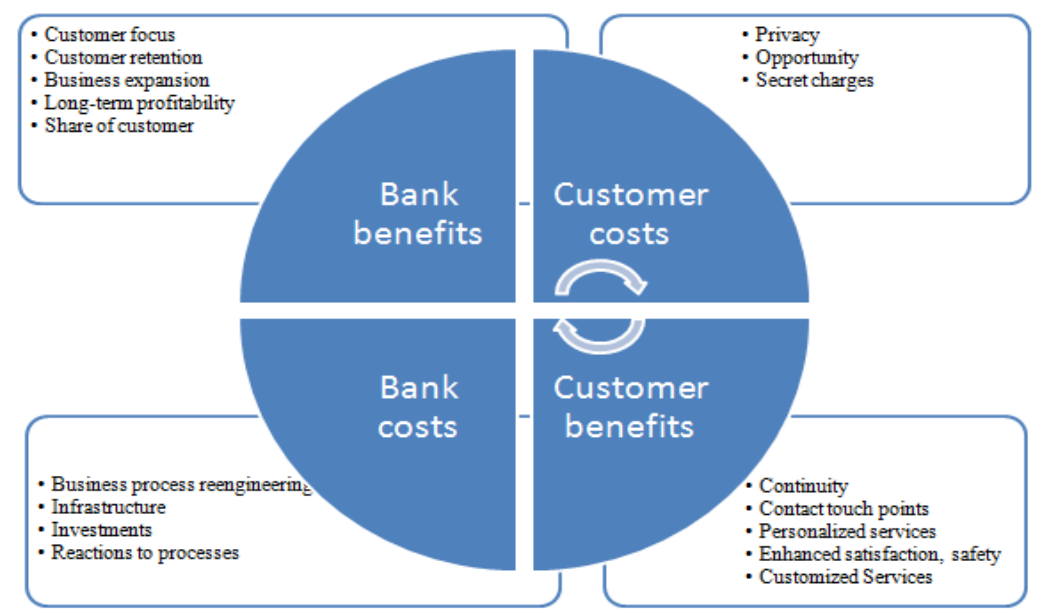

Source: CRM Practice in Banking Sector - Prime Bank Ltd. vs. EXIM Bank Ltd. February 29, 2012 Dept. of Finance \& Banking Jahangirnagar University, Savar, Dhaka -1342. p. 26

The steps for implementing the CRM system are (Brink, A., Berndt, A., 2009):

1. Strategy;

2. System analysis;

3. System design;

4. Implementation of the system;

5. System testing. 
There is no single solution for successful implementation of CRM because each company is specific and special, so this has to be approached in a specific manner.

\section{Influence of the CRM implementation on the profitability of the banks}

Consumer Relationship Management (CRM) proved in practice to be a successful strategy in the service industry. As the customers are increasingly sensitive to the prices and as their loyalty to a brand decreases, CRM plays a strategic role in the attraction of the clients to the banking sector. As in the past years, the competition in the banking sector became more intensive, the practice has shown that the successful implementation of the CRM philosophy in the banks leads to increase of revenues. (Mahesh A, Ganga B, Dubai, 2015)

Three most important profitability indicators for the banks are the following:

- ROA - Return on assets;

- ROE - Return on equity;

- NIM -Net interest margin.

In order to approach the calculation of the ROA indicator, some information is needed. First, it is necessary to know the amount of net revenues, and the next thing is to find the amount of the bank's assets. The ROA coefficient is obtained from the ratio of net revenues and bank assets.

For calculation of the next indicator of bank's profitability, ROE, it is necessary to divide the amount of net revenues with the amount of total share capital, and all of this information can be found in the Balance sheet of the bank.

In the end, the third most significant indicator of profitability is net interest margin-NIM, and it can be calculated by determining the net revenues from the bank's interests, and this information can be found in the Profit and Loss Statement of the bank or it can be obtained by deducting the bank's interest costs from their revenues from interest. Then, this is divided with the assets of the bank. NIM is calculated according to the following formula.

$$
\text { Net interest margin }=\frac{\text { Interest income }- \text { Interest expense }}{\text { Total assets }} \times 100
$$

HDFC bank (www.hdfcbank.com) is one of the biggest banks in India. This bank is registered by the Housing Development Financial Corporation Limited (HDFC), which is dealing with the financing of the residential construction in India. The Bank has huge funds of around USD 38 billion, distributed in over 1400 cities, and it has 2544 Branch offices. The products offered by this bank are the following: Retail banking, Wholesale Banking and Treasury. 
HDFC bank applies the CRM concept in its operations in order to implement its vision of unique bank, all in the goal of realisation of higher profit and customer satisfaction. It uses the services of the company CRM.next, which was founded in 2002 and operates in 11 different business areas. In order to successfully implement and apply the CRM software, it is necessary to harmonise the goals and strategies of the bank. With this software, CRM customers are provided with the secure access for creating, access and change of all relevant information continuously from any location, through the enabled IT solutions. During the introduction of CRM, the banks cannot forget the fact that this does not refer only to a new form of technology which will be applied in the bank, but this also represents a new business method. The banks today do not see CRM as the magical software, but as a key to success and crucial element of their operations.

There are seven steps for the successful implementation of HDFC's CRM solution.

1. CRM vision dictates which activities are necessary to implement in order to create a unique experience and that CRM is deeply engraved in culture consistently. The management team must constantly communicate instead of individual teams.

2. Creating a core team. This means that all members of the organisation share the inputs, which apply to all relevant customer information.

3. Properly configure the system. All interested parties must be involved in the study and communicate with each other in order to receive feedback, and thus form a captain of the CRM department, who will manage all advice and suggestions to improve the implementation of CRM.

4. Understanding all stakeholders. HDFC Bank clearly specified and explained the benefits of CRM implementation in relation to each role and function of the banking business, as clients work better if motivated and not forced.

5. Identify the Smart Automation shortcuts. CRM allows you to perform the integration of multiple systems that are used for regular records and update customer information.

6. The maturity of the CRM plan. It is necessary that the bank understands its key role in the CRM process and what are its benefits of using the same, and then move forward step by step.

7. Continuous maintenance of excitement and desire for development. One of the tips is to set a two-week focus on the results achieved with a regular update of the data. (http://www.hdfcbank.com/htdocs/common/pdf/corporate/HDFC-BankAnnualReport-2012-13.pdf) 
Table 1 Analysis of key profitability indicators in HDFC Bank for the period 2012-2016

\begin{tabular}{||l|c|c|c|c|c||}
\hline $\begin{array}{l}\text { Profitability } \\
\text { indicators }\end{array}$ & $\begin{array}{c}2012 . \\
(\%)\end{array}$ & $\begin{array}{c}2013 . \\
(\%)\end{array}$ & $\begin{array}{c}2014 . \\
(\%)\end{array}$ & $\begin{array}{c}2015 . \\
(\%)\end{array}$ & $\begin{array}{c}2016 . \\
(\%)\end{array}$ \\
\hline $\begin{array}{l}\text { Net interest } \\
\text { margin }\end{array}$ & 18,93 & 19,18 & 20,61 & 21,07 & 20,41 \\
\hline Return on assets & 1,52 & 1,68 & 1,72 & 1,73 & 1,73 \\
\hline Return on capital & 17,26 & 18,57 & 19,50 & 16,47 & 16,91 \\
\hline
\end{tabular}

Source: The financial reports of HDFC Bank from 2012 to 2016

The CRM philosophy or the business method was introduced in the HDFC operations in the period from 2008 to 2011 . The point of the instruction refers to the finding of the new solutions in order to achieve: view of the customer with 360 degrees, an increase of productivity in providing of services and improvement of cross-sales of products and services to the customers.

According to the comparative analysis from the previous table, it can be concluded that the profitability indicators have grown continuously, with mild oscillations. After the introduction of CRM in HDFC bank, there was also an increase in profit and revenues.

Figure 3. The trend of profit in HDFC Bank, from 2007 to 2016

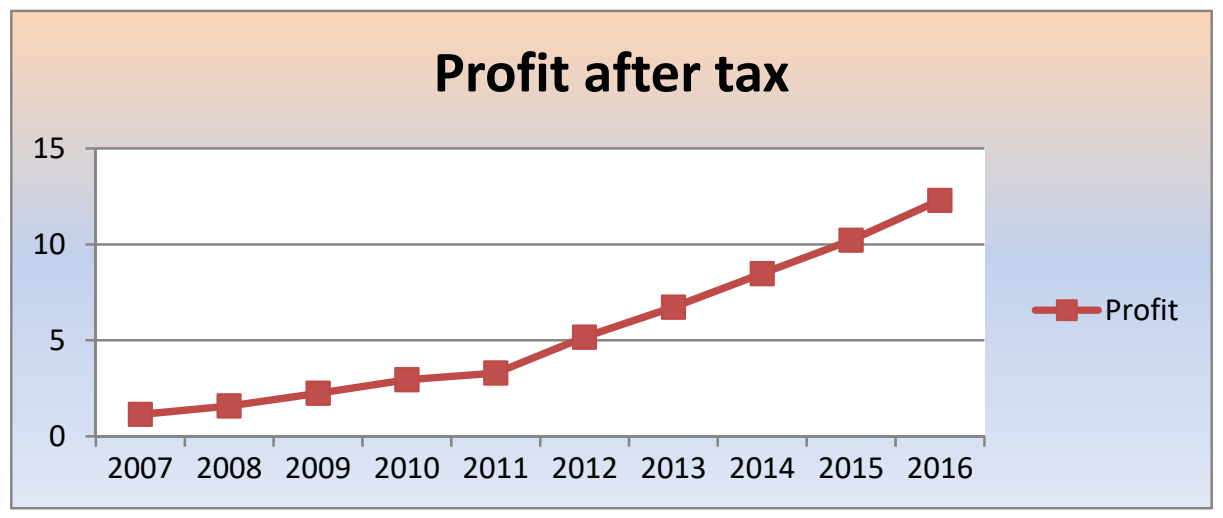

Source: http://www.moneycontrol.com/annual-report/hdfcbank/HDF01/2016

According to the presented Image No. 3 , the fact is that the profit has a growing tendency, observed for the period from 2007 to 2016. Since the introduction of the CRM in 2011, an increase of profit by almost four times was observed.

Emirates NBD bank is amongst the best banks in the world, with the seat in Dubai. This banking group was founded on October 16, 2007, with the merger of the second and the fourth largest banks in the United Arab Emirates (UAE). This 
banking group was made with the merger of Emirates Bank International (EBI) and National Bank of Dubai (NBD), with the goal of forming the banking champion which is able to provide increased value to the corporate, retail, private, Islamic and investment banking throughout the region.

The vision of the Emirates $N B D$ is to be recognisable at the global level, as the most valuable provider of financial services with the seat in the Middle East. The bank has over 220 Branch offices throughout the country and abroad. Its business is increasingly growing from year to year, so the number of customers increases by $30 \%$ each year. Its customers are highly digitalised so that the $90 \%$ of transactions are done over various online services through Branch offices. The introduction of the CRM concept in the operations of the ENBD bank started in 2013, setting the new goals it wants to reach each year. The launch of the Siebel CRM sales and marketing model in 2013, had the goal to provide the CRM platform which will be the centre of the $E N B D$ in order to provide the customers the possibility to focus on operationally efficient and completely digital banking.

Emirates NBD bank initiated the CRM implementation process in 2012 in order to provide the programme of excellence, which contributed to the significant improvements in providing services by obtaining feedback from the customers. Director of Marketing of the Emirates NBD bank, Vikram Krishna, pointed out that the key for the development of services in their bank is to provide superior services to the customers. The results after introduction of CRM show an increase in revenues, made thanks to a change in strategy in approach to the customers.

Table 2. Analysis of key profitability indicators in Emirates NBD Bank for the period 2007-2016

\begin{tabular}{||l|c|c|c|c|c|c|c|c|c|c||}
\hline $\begin{array}{l}\text { Profitability } \\
\text { indicators }\end{array}$ & $\begin{array}{l}2007 . \\
(\%)\end{array}$ & $\begin{array}{l}2008 . \\
(\%)\end{array}$ & $\begin{array}{l}2009 . \\
(\%)\end{array}$ & $\begin{array}{l}2010 . \\
(\%)\end{array}$ & $\begin{array}{l}2011 . \\
(\%)\end{array}$ & $\begin{array}{l}2012 . \\
(\%)\end{array}$ & $\begin{array}{l}2013 . \\
(\%)\end{array}$ & $\begin{array}{l}2014 . \\
(\%)\end{array}$ & $\begin{array}{l}2015 . \\
(\%)\end{array}$ & $\begin{array}{l}2016 . \\
(\%)\end{array}$ \\
\hline $\begin{array}{l}\text { Net interest } \\
\text { margin }\end{array}$ & 63.97 & 53.53 & 46.39 & 24.07 & 25.49 & 25.01 & 45.58 & 49.03 & 56.34 & 55.55 \\
\hline $\begin{array}{l}\text { Return on } \\
\text { assets }\end{array}$ & 1.58 & 1.37 & 1.19 & 0.82 & 0.89 & 0.86 & 1.00 & 1.31 & 1.70 & 1.56 \\
\hline $\begin{array}{l}\text { Return on } \\
\text { capital }\end{array}$ & 16.28 & 14.48 & 11.63 & 7.14 & 7.38 & 7.16 & 8.33 & 10.47 & 13.40 & 12.71 \\
\hline
\end{tabular}

Source: The financial statements of Emirates NBD Bank for the period 2007-2016

According to the presented table, it can be concluded that the profitability indicators have gown continuously, and especially since 2012 after CRM was introduced. So, for example, in 2016 compared to the primary 2012 the net interest margin increased by two times (from $25.49 \%$ to $55.55 \%$ ). 
On basis of the above image the increase of profitability since 2012 can be clearly seen after the introduction of the CRM concept in the operations of the Emirates $N B D$ and there was an increase of profit, so, for example, in 2012 when the implementation of CRM started and in the last observed year, 2016, an increase of net profit from $2.6 \%$ to $7.2 \%$ can be noticed, and that is almost three times higher percentage.

Figure 4. Trend growth in net profits Emirates NBD Bank from 2011 to 2016

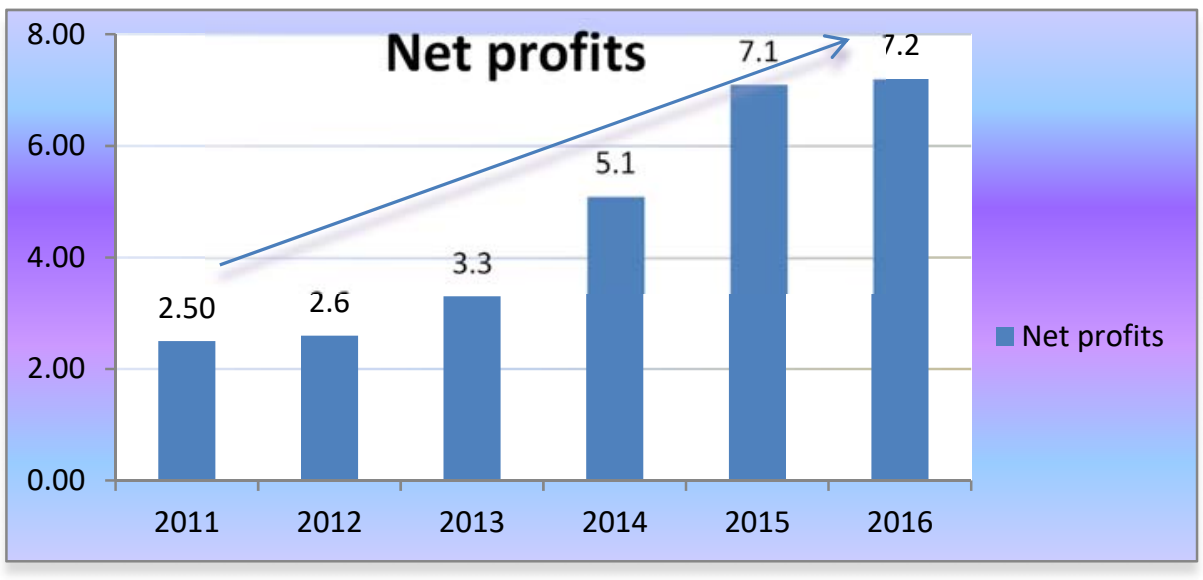

Source:http://www.emiratesnbd.com/plugins/FinanceManagement/AnnualReport/Annu alEnglish/EmiratesNBD_AnnualReport_2016.pdf

Intesa Sanpaolo banking group was established with the merger of Banca Intesa and Sanpaolo IMI in Italy. The leading banking group in the Italian market has a growing presence focused on Central and Eastern Europe, the Middle East and Northern Africa. Until 2010, the revenues of the bank were around USD 877.66 billion. Intesa Sanpaolo has Brach offices all around the world, around 1600 of them and over 8.3 million customers in the retail and commercial banking.

Introduction of the CRM concept in the Intesa Sanpaolo Group started in 2012 and included around 30 crucial employees, who attended training and educations. The implementation of the CRM was directed to two main goals: (www.efma.com)

1. It is necessary to make a cultural shift in the education of employees from Head Office in the entire RM network, where there are several courses directed to transformation of employees empowering them to achieve success and customer satisfaction;

2. Develop good technological solutions, with the goal of analysis of the great quantity of data, conduct necessary educations for obtaining the skills to conduct the analyses in real time. 
The results achieved after implementation of the CRM software in the Intesa Sanpaolo are reflected in increased satisfaction of customers and effectiveness in the sale of services. So, on average around 4.1 million interactions in real time occur in average over the mobile and online services per day. High level of adaptation of the statistical models led to increasing of the sale of debit cards by six times, by $+12 \%$. The investment for the introduction of the CRM software amounts to around USD 1 million.

Table 3. Analysis of Key Profitability Indicators in Intesa Sanpaolo Bank for the period 2007-2016

\begin{tabular}{|l|c|c|c|c|c|c|c|c|c|c||}
\hline \hline $\begin{array}{l}\text { Profitability } \\
\text { indicators }\end{array}$ & $\begin{array}{c}2007 . \\
(\%)\end{array}$ & $\begin{array}{c}2008 . \\
(\%)\end{array}$ & $\begin{array}{c}2009 . \\
(\%)\end{array}$ & $\begin{array}{c}2010 . \\
(\%)\end{array}$ & $\begin{array}{c}2011 . \\
(\%)\end{array}$ & $\begin{array}{c}2012 . \\
(\%)\end{array}$ & $\begin{array}{c}2013 . \\
(\%)\end{array}$ & $\begin{array}{c}2014 . \\
(\%)\end{array}$ & $\begin{array}{c}2015 . \\
(\%)\end{array}$ & $\begin{array}{c}2016 . \\
(\%)\end{array}$ \\
\hline $\begin{array}{l}\text { Net interest } \\
\text { margin }\end{array}$ & 45.63 & 19.86 & 16.06 & 19.57 & -50.47 & 12.26 & -47.58 & 9.69 & 17.28 & 21.84 \\
\hline $\begin{array}{l}\text { Return on } \\
\text { assets }\end{array}$ & 1.68 & 0.47 & 0.44 & 0.42 & -1.26 & 0.24 & -0.70 & 0.20 & 0.39 & 0.42 \\
\hline $\begin{array}{l}\text { Return on } \\
\text { capital }\end{array}$ & 15.88 & 3.87 & 4.50 & 5.09 & -16.29 & 2.12 & -4.31 & 1.08 & 2.99 & 6.06 \\
\hline
\end{tabular}

Source: The financial statements of Intesa Sanpaolo Bank for the period 2007-2016.

According to the presented Table 3, it can be noticed that there are some oscillations in the key indicators of profitability in the Intesa Sanpaolo bank for the observed period. So, after the initial introduction of the CRM concept in 2012, there is a mild increase in the observed indicators.

Figure 5. Consolidated profitability indicators for 2015 and 2016

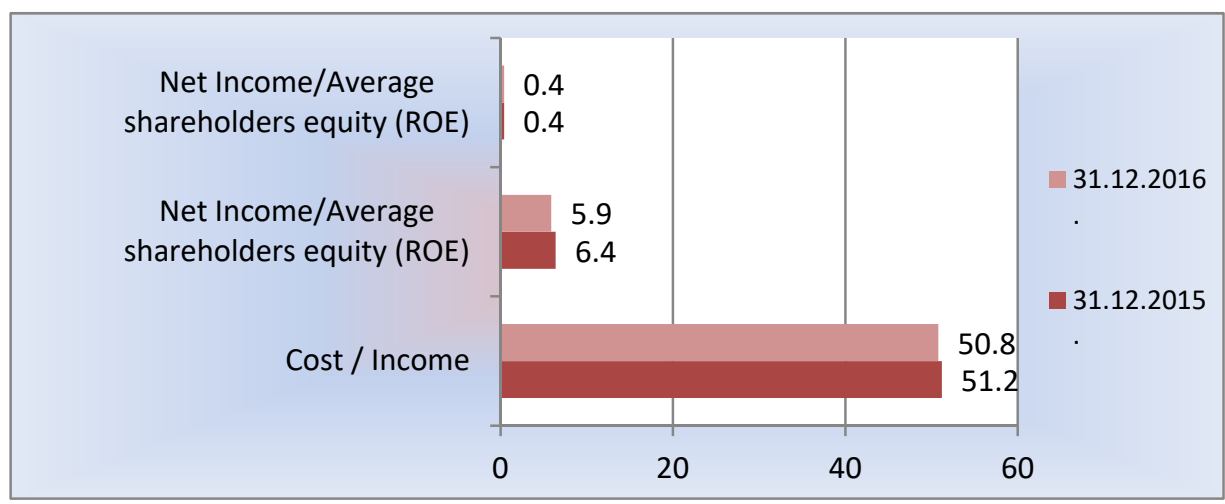

Source:http://www.group.intesasanpaolo.com/scriptIsir0/si09/contentData/view/contentref?id=CNT-05-00000004D7191 


\section{Conclusion}

The vision of a bank is to operate with a high profit. In the difficult and complex market conditions, this intention of the bank is becoming increasingly hard to achieve. So, for new conditions, it is necessary to have a new principle of operations, which is presented in a form of CRM concept. The goal of a bank is to retain the existing customers, increase the loyalty level, and all of this is enabled with the implementation of the new business strategy and philosophy-CRM. This concept enables the development of the bank and its survival, and on the other side also the individualised approach to the customer, meeting the needs, requests, and desires of the customer with the long-term character.

According to the conducted comparative analyses of key indicators of profitability on the example of three banks: HDFC bank, Emirates NBD Bank and Intesa Sanpaolo bank, which have introduced the new philosophy of business and operations-the CRM philosophy, the conclusion is reached that after introduction of CRM in the systems of these banks the profitability has increased significantly. However, it has to be pointed out that the effects of the implementation of CRM in the bank cannot be clearly notices in the short-term level, but the effects of the application of the CRM philosophy in the banks could be evaluated and analysed after certain longer period after the implementation. After the conducted comparative analyses of the profitability, of the selected banking groups and the obtained results, the conclusion is reached that the hypothesis of the paper has been proved.

\section{References}

Arsovski S., (2002), Quality Economics Management, University of Kragujevac, Kragujevac

Brink, A., Berndt, A.(2009): CustomerRelationshipManagement\&CustomerService, Juta andCo Ltd., Lansdowne

Forsyth, R .(2001): Six Major Impediments to Change and How to Overcome Them in CRM.

Kotler Ph., Keller K. L .(2006): Marketing Management. Data Status.Belgrade, 2006.

Mahesh Agnihotri; Ganga Bhavani (2015): "Impact of Customer Relationship Management Practices on the Profitability of UAE Banks"A Comparative Study; Journal of Business Management \& Social Sciences Research; ISSN No: 2319-5614, Dubai, June, 2015.

Parasuraman, A., Zeithaml, VA, \& Berry, L. L. (1988). SERVQUAL: a multiple-item scale for measuring consumer perception of service quality. Journal of Retailing, 64 (1)

Parvatiyar A., Sheth J,:,,Conceptualframework of customerelationshipmanagement“", 2001.

Peppers D., Rogers M., Managing Managing Relationships, John Wiley \& Sons, Inc., Hoboken, NJ., 2004.

Savar, Dhaka (2012). CRM Practice in Banking Sector - Prime Bank Ltd. vs. EXIM Bank Ltd Dept. of Finance \& Banking. Jahangirnagar University, -1342.

Sexauer H.J, ReimannE (2006): WarumFinanzdienstelerenorm in CRM investieren und dennochnurStückwerkproduzieren, www.wiwi.uni-frankfurt.de

Unković M., Stakić B., (2011) Foreign Trade and Foreign Exchange Operations, Singidunum University, Belgrade 
Zelenović Vera, (2012), Marketing in Banking, Subotica

http://www.hdfcbank.com/aboutus/awards/default.htm

http://www.moneycontrol.com/annual-report/hdfcbank/HDF01/2016

http://www.emiratesnbd.com/plugins/FinanceManagement/AnnualReport/AnnualEnglish/Em iratesNBD_AnnualReport_2016.pdfhttp://

www.efma.com/innovations/innovations-library/?search-inno=

http://www.group.intesasanpaolo.com/scriptIsir0/si09/contentData/view/content-ref?id=CNT05-00000004D7191

http://www.ef.uns.ac.rs/Download/elektronsko_upravljanje_odnosima_sa_kupcima/2014-0326-CRM-Definicija.pdf

http://www.ef.uns.ac.rs/Download/elektronsko_upravljanje_odnosima_sa_kupcima/2014-0510-Arhitektura-CRM.pdfhttp://www.tutorialreports.com/software/crm/analytical.php

http://www.preact.co.uk/why_crm/how-businesses-benefit

http://www.hdfcbank.com/htdocs/common/pdf/corporate/HDFC-Bank-AnnualReport-201213.pdf

\section{EFEKTI PRIMENE CRM KONCEPTA NA PROFITABILNOST BANAKA}

Apstrakt: CRM (engl. Consumer Relationship Management) je koncept novijeg datuma. Razvoj i uvođenje ovog koncepta u bankarsko poslovanje započinje '90ih godina. Zbog kompleksnih tržišnih uslova i današnjeg ambijenta u kom posluju banke, neophodan je novi način poslovanja, koji će brzo i efikasno obezbediti prepoznavanje klijenata. Ovaj koncept poslovanja u potpunosti zamenjuje tradicionalni način poslovanja banke, gde se fokus stavlja na klijente, njegove potrebe i želje. CRM koncept omogućava banci da kvalitetnim bankarskim proizvodima i usluga odgovori na individualizovane zahteve klijenata. Ovim banke uspevaju da se izbore sa oštrom konkurencijom i ostvare profit. Cilj ovog rada je da se sagleda značaj, razvoj i implementacija CRM-a u banke. Radom se nastoji dokazati hipoteza: Uvođenje CRM filozofije u bankarsko poslovanje dovodi do povećane profitabilnosti banke.

Ključne reči: CRM koncept, profitabilnost, bankarski sektor

\section{Authors' biographies}

Suzana Stevanović graduated from the Faculty of Business Economics in Bijeljina, University of East Sarajevo. During her studies she received scholarships from the Municipality of Bijeljina and the Ministry of Education and Culture of the Republic of Srpska. She currently works at the Faculty of Business Economics as a senior assistant. The title of assistant was awarded in 2012, a narrow scientific field: Business Finance. Subjects taught: Business Finance, Theory and Balance Analysis, Financial Markets, Investing in Securities. She obtained the title of senior assistant in 2016. She completed her Master studies at the Faculty of Business Economics in 2016, with an average of 10.00. The theme of the Master's work theme was "Influence of the structure of banks' capital on the 
performance of enterprises and the competitiveness of the economy in Bosnia and Herzegovina". For funding this work she received a scholarship from the Municipality of Bijeljina. Since 2012 she has been participating in the Organizing Committee of the magazine "New Economist", as well as the EkonBiz Scientific Conference organised by the Faculty of Business Economics in Bijeljina. Also, she was appointed Secretary of the Department of Accounting, Auditing and Business Finance in 2016, the University of East Sarajevo. She is a Ph.D. student, at the Faculty of Economics in Subotica, University of Novi Sad, second year.

Zvjezdana Gavrilović graduated from the Faculty of Economics in East Sarajevo in 2007. She obtained an MSc in 2012. She is a Senior Teaching Assistant on Marketing, International Marketing, Marketing Services, Consumer Behaviour and Business organization at the Faculty of Business Economics in Bijeljina. She is also a PhD student at the Faculty of Business Economics in Bijeljina. 